\title{
Evidence to Support Inclusion of Pharmacogenetic Biomarkers in Randomised Controlled Trials
}

\author{
Danielle Johnson ${ }^{1, *} \mathbb{\infty}$, Dyfrig Hughes $\left.{ }^{2} \mathbb{(}\right)$, Munir Pirmohamed ${ }^{3}\left(\mathbb{C}\right.$ and Andrea Jorgensen ${ }^{1}$ \\ 1 Institute of Translational Medicine, Department of Biostatistics, University of Liverpool, \\ Waterhouse Building, 1-5 Brownlow Street, Liverpool L69 3GL, UK \\ 2 Centre for Health Economics and Medicines Evaluation, Bangor University, Ardudwy, Normal Site, \\ Bangor LL57 2PZ, UK \\ 3 MRC Centre for Drug Safety Science and Wolfson Centre for Personalised Medicine, \\ Institute of Translational Medicine, Waterhouse Building, 1-5 Brownlow Street, Liverpool L69 3GL, UK \\ * Correspondence: danielle.johnson@liverpool.ac.uk
}

Received: 30 July 2019; Accepted: 19 August 2019; Published: 1 September 2019

\begin{abstract}
Pharmacogenetics and biomarkers are becoming normalised as important technologies to improve drug efficacy rates, reduce the incidence of adverse drug reactions, and make informed choices for targeted therapies. However, their wider clinical implementation has been limited by a lack of robust evidence. Suitable evidence is required before a biomarker's clinical use, and also before its use in a clinical trial. We have undertaken a review of five pharmacogenetic biomarker-guided randomised controlled trials (RCTs) and evaluated the evidence used by these trials to justify biomarker inclusion. We assessed and quantified the evidence cited in published rationale papers, or where these were not available, obtained protocols from trial authors. Very different levels of evidence were provided by the trials. We used these observations to write recommendations for future justifications of biomarker use in RCTs and encourage regulatory authorities to write clear guidelines.
\end{abstract}

Keywords: pharmacogenetics; biomarker; adverse drug reactions; RCT; evidence

\section{Introduction}

The growing field of pharmacogenetics, which studies the effect of genetic biomarkers on the likelihood of treatment response or adverse drug reactions (ADRs) [1], offers an important opportunity to increase the chances of drug benefit and/or reduce the risk of harm [2-5]. A biomarker is defined as "a characteristic that is objectively measured and evaluated as an indicator of normal biological processes, pathogenic processes, or pharmacologic responses to a therapeutic intervention" [6]. Both germline and somatic genetic biomarkers are being used increasingly to personalise treatments across a wide range of disease areas, including cancer [7,8], thromboembolic disease [9], and autoimmune disease [10], as well as to diagnose disease and provide patient prognosis.

Many drugs are withdrawn from the market due to lack of efficacy and/or ADRs [11-13], and the latter are a major cause of hospital admissions, morbidity, and mortality [14,15]. ADRs are associated with high cost in terms of both time and resources, as well as the negative effects on patient health. There is therefore great potential for genetic biomarker testing to improve the efficacy, safety and cost-effectiveness of medicines. Reviews of economic evaluations of medicines with actionable pharmacogenetic information found the majority of tests to be cost-effective or even cost-saving $[16,17]$. For example, screening for the $H L A-B^{*} 57: 01$ allele has significantly reduced the incidence of severe ADRs associated with abacavir [18], and has been recommended as a cost-effective intervention [19]. Although it should not be assumed that all pharmacogenetic testing will be cost-effective [20], reductions in the cost of testing and efficiency improvements may see the implementation of more pharmacogenetic tests into clinical practice. 
While the US Food and Drug Administration (FDA) lists over 200 drugs with pharmacogenetic information included in their labels [21], their wider clinical implementation has been limited [22-26]. There are many reasons for this, including the lack of robust evidence of clinical utility $[27,28]$. Prior to the approval and implementation of biomarker tests in clinical practice, evidence is required of the test's clinical utility [29-32] and the gold-standard approach to do this according to guidelines is the randomised controlled trial (RCT) [33-35]. A lack of well-designed trials has been cited as one of the main obstacles contributing to the delay in translation of pharmacogenetic discoveries into clinic $[28,30,36,37]$. Several biomarker-guided trial ('BM trial') designs have been proposed for this purpose [38-40], and our previously developed online tool, www.bigted.org, provides information about each to guide those designing such a trial [39]. However, before embarking on a BM trial, it is important that robust evidence of the biomarker's utility and validity is available to justify its inclusion in the trial's design [41] — without this, there is a risk of wasting money and time on an inappropriate biomarker. Nonetheless, the nature and extent of evidence required, and how it should be compiled, is unclear. More guidance exists on the evidence required for interventions to be included in a trial than for biomarker inclusion, although an integral biomarker assay is just as important a component of the trial $[41,42]$.

With this in mind, we undertook a literature review with the aim of reviewing sources of evidence used to justify five previously published pharmacogenetic BM trials. These were chosen to represent different pharmacogenetic biomarker applications. We explored the nature and extent of previous evidence on the association of the included biomarkers with treatment response that had been used to justify their inclusion. We were not concerned with the findings of the trials, instead focusing purely on the evidence cited to justify the inclusion of biomarker(s) within their design. Indeed, we acknowledge that other trials will have been conducted since the publication of the trials included in our review which will have added to the evidence base on the use of the drugs under study. In light of our findings, we also reflected on and provided recommendations on how such evidence should be compiled by those planning future BM trials.

\section{Details of Included Trials}

To allow us to explore in detail the evidence compiled for each trial, we limited our review to five recently published BM trials. These were chosen carefully to ensure that they were representative of the available trials and spanned a range of different biomarker applications. We felt it important to not only include trials using biomarkers in a way that has been well-characterised (e.g., for targeted therapies), but also those incorporating biomarkers for less well-characterised purposes (e.g., improving medication adherence). The five chosen trials used biomarkers for prevention of ADRs [10], improving efficacy [9], choosing targeted therapies [43], improving medication adherence [44,45], and improving quality of life [46]. Summary details of each trial are provided in Table 1 and full details of data extracted are located in the Supplementary Materials. The first trial (TPMT: AZA Response to Genotyping and Enzyme Testing, TARGET, 2011) explored whether TPMT genotyping helped prevent ADRs associated with azathioprine [10,47]. A second trial (European Pharmacogenetics of Anticoagulant Therapy, EU-PACT, 2013) tested whether a genotype-guided approach to calculating therapeutic dose of the anticoagulant, warfarin, led to improved efficacy and reduced the incidence of ADRs [9]. The third trial (SHIVA, 2015) explored the utility of an approach that used genotyping to match patients to molecularly targeted therapies [43]. A fourth trial (Genotype-guided statin therapy, GGST statin trial, 2018) explored whether using genotype testing improved medication adherence and subsequently statin efficacy $[44,45,48]$. The final trial (NCT02664350) investigated the use of genotyping to reduce pain associated with cancer [46]. 
Table 1. Details of selected trials. Start year denotes year the first patient was recruited. BM trial (biomarker-guided trial) design is the design as selected by using the BiGTeD online resource [39].

\begin{tabular}{|c|c|c|c|c|c|c|c|c|c|c|c|c|}
\hline $\begin{array}{l}\text { Registration } \\
\text { Number }\end{array}$ & $\begin{array}{l}\text { Trial } \\
\text { Name }\end{array}$ & $\begin{array}{l}\text { Start } \\
\text { Year }\end{array}$ & $\begin{array}{c}\text { Year of } \\
\text { Results } \\
\text { Publication }\end{array}$ & $\begin{array}{l}\text { Paper References } \\
\text { Taken from }\end{array}$ & BM Trial Design & Biomarker & $\begin{array}{l}\text { Drug of } \\
\text { Interest }\end{array}$ & $\begin{array}{c}\text { Sample Size } \\
\text { (n Randomised) }\end{array}$ & $\begin{array}{c}\text { Age of } \\
\text { Participants }\end{array}$ & $\begin{array}{c}\text { Sex of } \\
\text { Participants }\end{array}$ & Ethnicity of Participants & $\begin{array}{l}\text { Study } \\
\text { Location }\end{array}$ \\
\hline \multirow{2}{*}{ ISRCTN30748308 } & \multirow{2}{*}{$\begin{array}{c}\text { TARGET } \\
\text { (protocol) } \\
{[10,47]}\end{array}$} & \multirow{2}{*}{2005} & \multirow{2}{*}{2011} & \multirow{2}{*}{$\begin{array}{l}2005 \text { protocol } \\
\text { obtained from authors }\end{array}$} & \multirow{2}{*}{$\begin{array}{l}\text { Biomarker strategy } \\
\text { design (without } \\
\text { biomarker assessment } \\
\text { in control arm) }\end{array}$} & \multirow{2}{*}{ TPMT } & \multirow{2}{*}{ Azathioprine } & \multirow[b]{2}{*}{333} & $\begin{array}{l}\text { Mean } 43.2 \\
\text { (control) }\end{array}$ & $\begin{array}{l}50.6 \% / 49.4 \% \mathrm{~F} / \mathrm{M} \\
\text { (control) }\end{array}$ & $\begin{array}{c}92.2 \% \text { white, } 4.8 \% \text { South } \\
\text { Asian, } 0.6 \% \text { Black, } 2.4 \% \\
\text { mixed/other (control) }\end{array}$ & \multirow{2}{*}{ UK } \\
\hline & & & & & & & & & $\begin{array}{l}\text { Mean } 41.0 \\
\text { (genotyped) }\end{array}$ & $\begin{array}{c}50.3 \% / 49.7 \% \mathrm{~F} / \mathrm{M} \\
\text { (genotyped) }\end{array}$ & $\begin{array}{l}89.8 \% \text { white, } 7.2 \% \text { South } \\
\text { Asian, } 3.0 \% \text { Black, } 0 \% \\
\text { mixed/other (genotyped) }\end{array}$ & \\
\hline \multirow{3}{*}{ NCT01119300 } & \multirow{3}{*}{$\begin{array}{c}\text { EU-PACT } \\
\text { [49] }\end{array}$} & \multirow{3}{*}{2011} & \multirow{3}{*}{2013} & \multirow{3}{*}{$\begin{array}{c}\text { 2009 paper } \\
10.2217 / \text { pgs.09.125 }\end{array}$} & \multirow{3}{*}{$\begin{array}{l}\text { Biomarker strategy } \\
\text { design (without } \\
\text { biomarker assessment } \\
\text { in control arm) }\end{array}$} & $\mathrm{CYP2C9*2}$ & \multirow{3}{*}{ Warfarin } & \multirow{3}{*}{455} & $\begin{array}{c}\text { Mean } 66.9 \\
\text { (control) }\end{array}$ & $\begin{array}{c}\begin{array}{c}42.1 \% / 57.9 \% \mathrm{~F} / \mathrm{M} \\
\text { (control) }\end{array} \\
\end{array}$ & $\begin{array}{c}98.7 \% \text { white, } 0.9 \% \text { Black, } \\
0.4 \% \text { Asian (control) }\end{array}$ & \multirow{3}{*}{$\begin{array}{c}\text { UK, } \\
\text { Sweden }\end{array}$} \\
\hline & & & & & & CYP2C9*3 & & & \multirow{2}{*}{$\begin{array}{l}\text { Mean } 67.8 \\
\text { (genotyped) }\end{array}$} & \multirow{2}{*}{$\begin{array}{c}35.8 \% / 64.2 \% \mathrm{~F} / \mathrm{M} \\
\text { (genotyped) }\end{array}$} & \multirow{2}{*}{$\begin{array}{l}98.2 \% \text { white, } 1.3 \% \text { Black, } \\
0.4 \% \text { Asian (genotyped) }\end{array}$} & \\
\hline & & & & & & VKORC1 & & & & & & \\
\hline \multirow{3}{*}{ NCT01771458 } & \multirow{3}{*}{$\begin{array}{c}\text { SHIVA } \\
{[43]} \\
\text { (protocol) }\end{array}$} & \multirow{3}{*}{2012} & \multirow{3}{*}{2015} & \multirow{3}{*}{$\begin{array}{l}2014 \text { protocol } \\
\text { obtained from authors }\end{array}$} & \multirow{3}{*}{ Enrichment design } & $\begin{array}{c}\text { Hormone receptors } \\
\text { pathway }\end{array}$ & \multirow{3}{*}{$\begin{array}{l}\text { Targeted } \\
\text { chemotherapy } \\
\text { agent, } \\
\text { based on } \\
\text { genotyping }\end{array}$} & \multirow{3}{*}{195} & $\begin{array}{l}\text { Median } 63 \\
\text { (control) }\end{array}$ & $\begin{array}{c}72 \% / 28 \% \mathrm{~F} / \mathrm{M} \\
\text { (control) }\end{array}$ & \multirow{3}{*}{ Not reported } & \multirow{3}{*}{ France } \\
\hline & & & & & & $\begin{array}{c}\text { PI3K/AKT/mTOR } \\
\text { pathway }\end{array}$ & & & $\begin{array}{l}\text { Median } 61 \\
\text { (genotyped) }\end{array}$ & $\begin{array}{c}61 \% / 39 \% \mathrm{~F} / \mathrm{M} \\
\text { (genotvped) }\end{array}$ & & \\
\hline & & & & & & RAF/MEK pathway & & & (genotyped) & (genotyped) & & \\
\hline \multirow{2}{*}{ NCT01894230 } & \multirow{2}{*}{$\begin{array}{c}\text { GGST } \\
\text { statin trial } \\
{[44]}\end{array}$} & \multirow{2}{*}{2013} & \multirow{2}{*}{2018} & \multirow{2}{*}{$\begin{array}{c}2016 \text { paper } \\
10.2217 / \text { pgs-2016-0065 }\end{array}$} & $\begin{array}{c}\text { Biomarker strategy } \\
\text { design (with biomarker }\end{array}$ & & & & $\begin{array}{l}\text { Mean 62.5 } \\
\text { (control) }\end{array}$ & $\begin{array}{c}65.8 \% / 34.2 \% \mathrm{~F} / \mathrm{M} \\
\text { (control) }\end{array}$ & $\begin{array}{c}80.3 \% \text { white, } 14.5 \% \text { Black, } \\
5.3 \% \text { other (control) }\end{array}$ & \\
\hline & & & & & $\begin{array}{l}\text { assessment in } \\
\text { control arm) }\end{array}$ & SLCO1B1*5 & Any statın & 159 & $\begin{array}{l}\text { Mean } 62.7 \\
\text { (genotyped) }\end{array}$ & $\begin{array}{c}49.4 \% / 50.6 \% \mathrm{~F} / \mathrm{M} \\
\text { (genotyped) }\end{array}$ & $\begin{array}{c}79.5 \% \text { white, } 16.9 \% \text { Black, } \\
3.6 \% \text { other (genotyped) }\end{array}$ & USA \\
\hline NCT02664350 & $\mathrm{n} / \mathrm{a}[46]$ & 2016 & $\begin{array}{c}\text { Results } \\
\text { not yet } \\
\text { published }\end{array}$ & $\begin{array}{c}2018 \text { paper } \\
\text { 10.1016/j.cct.2018.03.001 }\end{array}$ & $\begin{array}{c}\text { Biomarker strategy } \\
\text { design (without } \\
\text { biomarker assessment } \\
\text { in control arm) }\end{array}$ & CYP2D6 & Opioids & 200 (forecast) & $\begin{array}{c}\text { Not } \\
\text { available }\end{array}$ & Not available & Not available & USA \\
\hline
\end{tabular}


For each trial, we identified each piece of evidence referenced in the introduction section of a protocol or design paper associated with the trial, and extracted details of the publication year (Figure 1), study design, drug of interest, biomarker used, sample size, country of origin, and the age, sex and ethnicity of participants for each trial. For trials that did not have a published protocol or design paper, we used protocols obtained from contacting the authors (TARGET), or from the results paper Supplementary Information (SHIVA). Full details of data extracted are found in Table 1. Figures were made using RStudio (version 1.1.453, RStudio Team, Boston, MA, USA) [50], particularly the 'formattable' package [51], and LucidChart [52].

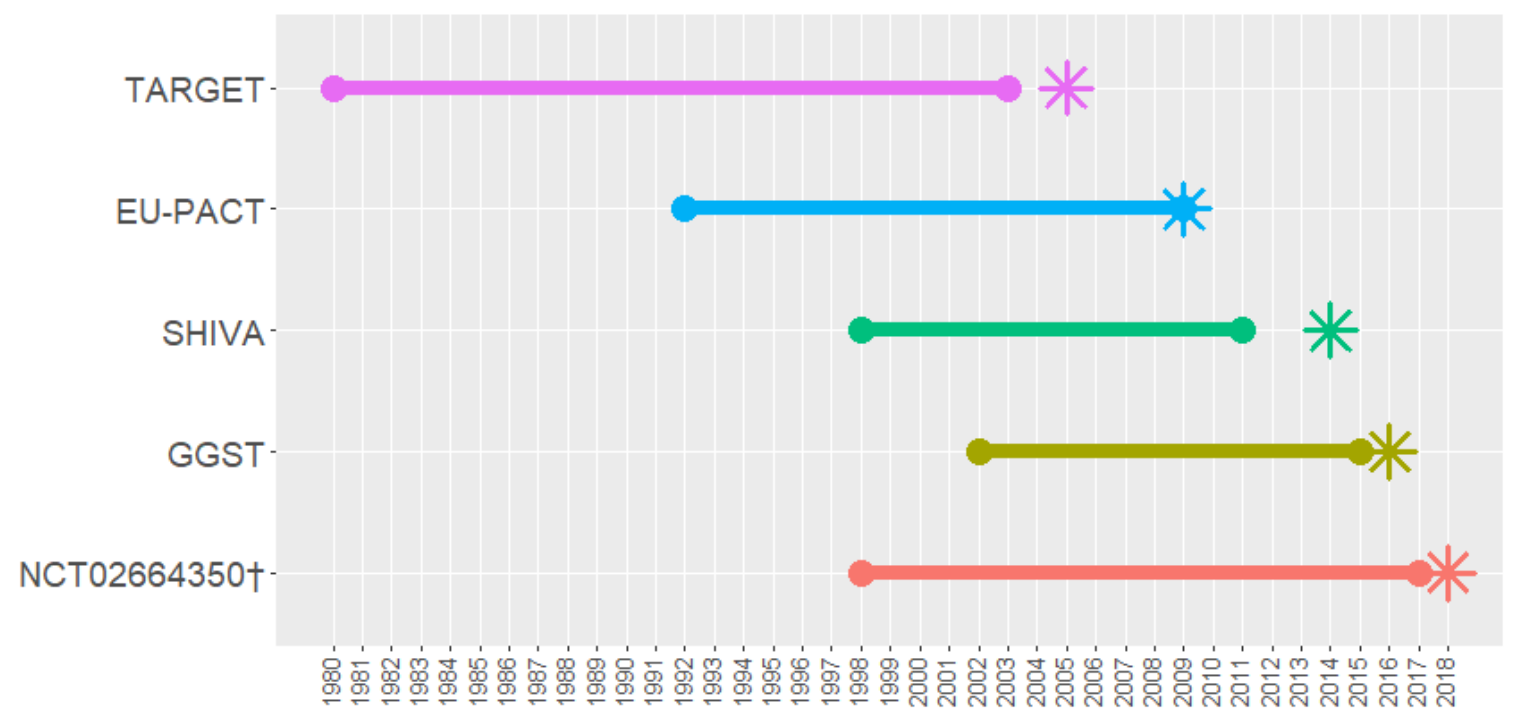

Figure 1. Timings of publications cited by each trial. Star icons indicate the date of publication of the paper or protocol references were extracted from. tresults not yet published.

\section{TARGET}

TARGET (ISRCTN30748308) began recruitment in 2005 and investigated the use of TPMT genotyping to prevent adverse reactions to azathioprine in patients with inflammatory disease $[10,53]$. The trial randomised inflammatory disease patients (in gastroenterology and rheumatology) 1:1 to genotyping or non-genotyping arms. In the genotyping arm, clinicians were made aware of each patient's TPMT status and the implications of this on dosing prior to commencing azathioprine treatment. Patients in the non-genotyping arm received standard azathioprine dosing.

TARGET used a biomarker strategy design without biomarker assessment in the control arm [39], Evidence used to justify use of the genotype test spanned the longest time frame of all trials, from 1980 to 2003 (Figure 2). The oldest evidence cited by the trial was a 1980 observational cohort study that proposed a monogenic inheritance pattern for the activity of the TPMT enzyme [54]. Also cited was a 1989 case-control study that compared TPMT enzyme activity in patients who had adverse reactions to thiopurines to a control group that had suffered no reaction [55]. The study showed that patients who had the adverse reaction had extremely low TPMT activity. In total, 11 observational studies were cited, consisting of 9 cohort studies [54,56-63], 1 case control study [55], and 1 study of enzymatic assay use in the UK [64]. A 2001 systematic review of pharmacogenetics in reducing ADRs was cited, although this review was not specific to azathioprine or TPMT. 


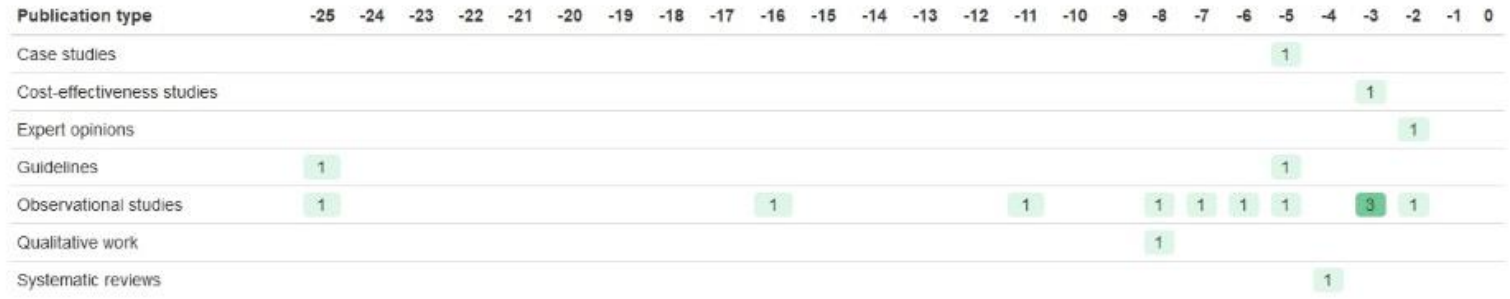

Figure 2. Evidence cited by the TARGET trial to justify inclusion of the TPMT biomarker, relative to the publication of the 2005 protocol [47].

The most recent evidence was an expert opinion by Seidman, 2003 [65]. A 2002 Canadian cost-effectiveness analysis [66], a 2000 case study [67], and a 1997 questionnaire of UK clinicians were also cited [68]. The authors also cited a 2000 guideline from the British Society of Rheumatology, which could not be located online.

\section{EU-PACT}

The EU-PACT study (NCT01119300) was a large, single-blind, randomised European trial of genotype-guided dosing of warfarin [9,49,69-71]. Patients in this trial were randomised 1:1 to genotype-guided or control groups, stratified by centre and treatment indication. Those in the genotype-guided group were genotyped for CYP2C9 and VKORC1 and dosed according to an algorithm that included both genetic and clinical factors. The control group received a standard dosing regimen guided by clinical factors only.

This trial also used a biomarker strategy design without biomarker assessment in the control arm [39]. The published protocol cited mostly observational studies as evidence (Figure 3). These ranged from a 1992 retrospective cohort study [72] to several 2009 studies [73-75]. This includes a 2009 genome-wide association study (GWAS) that showed the implications of specific CYP2C9, VKORC1, and CYP4F2 genes on warfarin dosing. Also cited were editorials [76,77], cost-effectiveness analyses [78,79], and a literature review of economic evaluations [80]. No previous RCTs were cited.

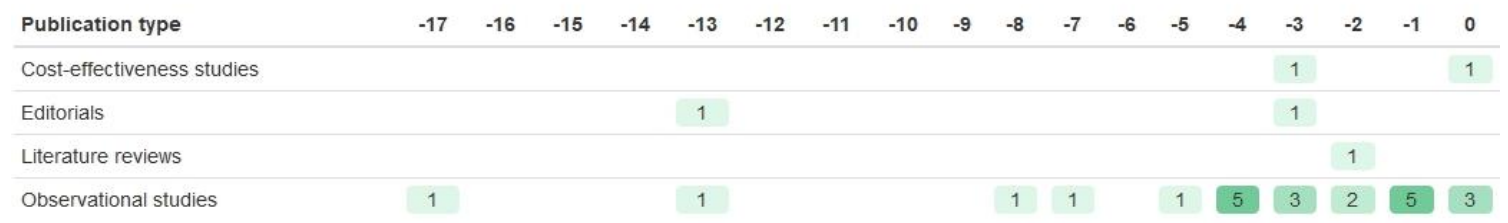

Figure 3. Evidence cited by the EU-PACT trial to justify inclusion of the CYP2C9 and VKORC1 biomarkers, relative to the publication of the 2009 published protocol [49].

\section{SHIVA}

The SHIVA trial (NCT01771458) was a French proof-of-concept histology-agnostic phase II trial using an enrichment design [39] that recruited patients with any metastatic solid cancer to receive treatment with targeted agents $[43,81,82]$. After analysis of their tumour, patients with mutations that matched an available drug were randomised 1:1 to receive targeted treatment or to physician's choice treatment.

The total evidence cited in the protocol ranged from 1998 to 2011 (Figure 4). Three RCTs were cited [83-85]. Two of these were trials of gefinitib in lung cancer [83,84]. Another RCT cited was an investigation of trastuzumab in HER2+ breast cancer patients, a combination that was investigated in SHIVA [85]. Two observational studies were cited [86,87], along with a contemporaneous editorial commenting on the validity of one of these studies [88]. 


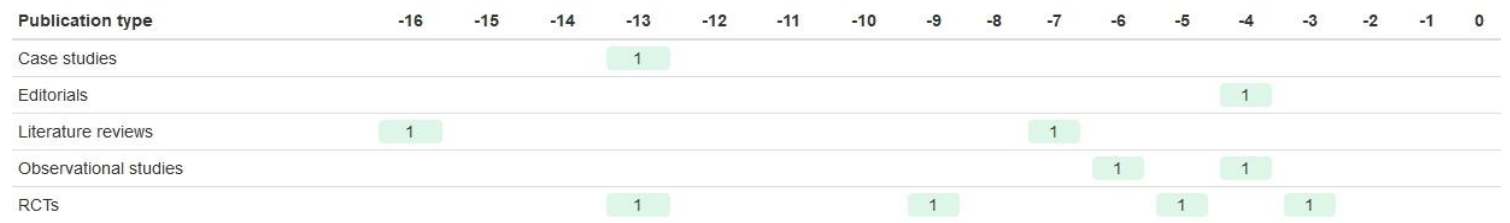

Figure 4. Evidence cited by the SHIVA trial to justify inclusion of the biomarkers, relative to the publication of the 2014 protocol (included in Supplementary of a 2015 paper [43]). RCT = randomised controlled trial.

The paper reporting on the results of this trial included an 'Evidence before this study' box [43]. This detailed a literature search performed prior to the start of the trial, which identified several observational cohort studies [87,89-92] and RCTs [93-95].

\section{GGST Statin Trial}

The SLCO1B1 genotype guided statin therapy (GGST) trial (NCT01894230) investigated the utility of using genotyping to increase adherence to statins and promote lower cholesterol in patients with cardiovascular disease and a history of statin-induced side effects $[44,45,48]$. Patients were genotyped and then randomised 1:1 to receive genotype information to guide their care, or to usual care alone. The primary outcome in this trial was medication adherence, as assessed by a standard questionnaire. The aim of the trial was to improve adherence by showing patients that treatment includes an assessment of the risks (real and perceived) of statin-induced side-effects [44]. The trial used a biomarker strategy with biomarker assessment in the control arm design [39].

This trial cited a large number of references ranging from 2002 to 2015 (Figure 5). Five sets of guidelines from four separate bodies were cited [96-100], alongside an epidemiology report from the American Heart Association [101]. Seven literature reviews were cited [102-108], alongside two editorials $[109,110]$. This trial also cited the largest number of observational studies, a total of eleven (consisting of 1 case control study [111], 9 cohort studies [112-120], and 1 cohort/meta-analysis study [121]). In contrast to the large amount of observational study evidence, the trial only cited one RCT [122]. Two further references were sub-studies of larger RCTs [123,124]. A 2013 Cochrane review was also cited [125].

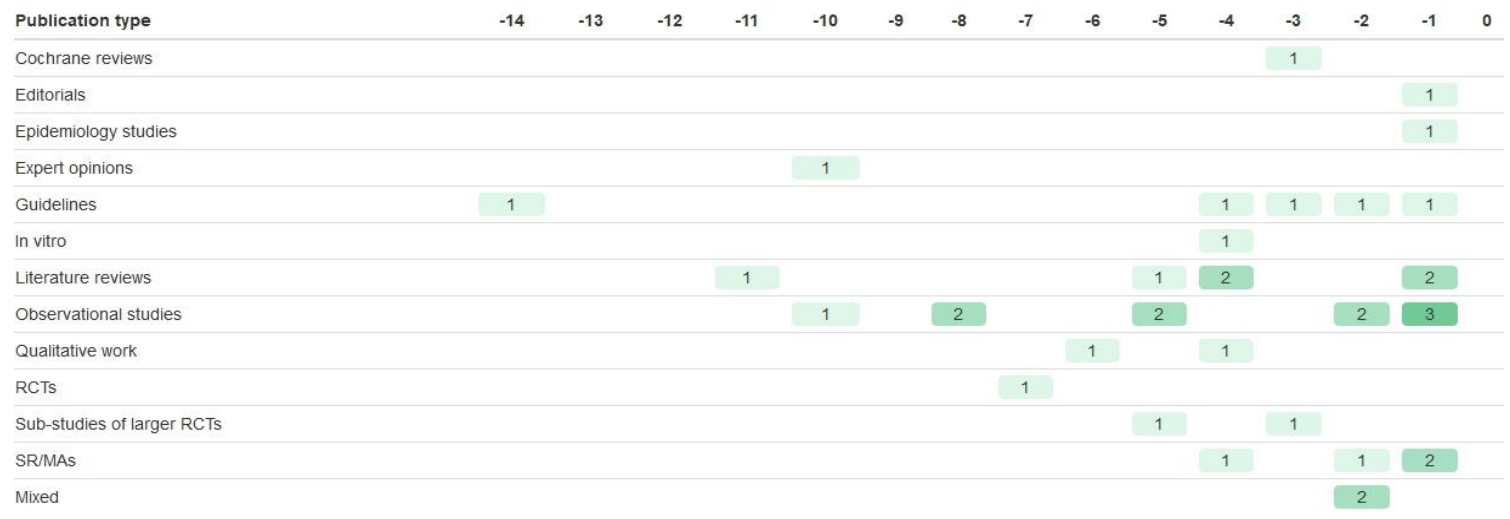

Figure 5. Evidence cited by the GGST statin trial to justify inclusion of the SLCO1B1 biomarker, relative to the publication of the 2016 rationale and design paper [44]. 'Mixed' refers to papers that used a mixture of two or more of the other publication types. RCT = randomised controlled trial $\mathrm{SR} / \mathrm{MAs}=$ systematic reviews/meta-analyses.

The authors cited one systematic review [126] and three meta-analyses [127-129]. The systematic review [126] assessed the quality of included studies using ISPOR guidelines [130], and one metaanalysis [129] evaluated quality using the Newcastle-Ottawa scale [131]. The other two meta-analyses 
were published by the Cholesterol Treatment Trialists' Collaborators (CTTC) group [127,128], a group established in 1994 to perform meta-analyses of long-term and large-scale trials of lipid intervention therapies [132].

The meta-analyses by the CTTC group were both done on the same large data set of $n=174,149$ participants from 27 RCTs $[127,128]$. Each RCT had to have a recruitment target of $>1000$ participants, and have a minimum 2 year treatment duration. The meta-analyses collated individual participant data (IPD). These meta-analyses did not assess the quality of the included studies.

\section{Precision Medicine Guided Treatment for Cancer Pain}

This trial (NCT02664350) used a biomarker strategy design without biomarker assessment in the control arm, and recruited patients with solid tumours and metastases to investigate CYP2D6-guided dosing of opioids to manage pain [46]. Patients with pain scores of $\geq 4$ (on a scale of 1-10) were randomised 1:1 to genotype-guided or conventional pain management strategies. This trial did not assign treatments to patients, but provided recommendations to clinicians based on CYP2D6 genotyping. Patients with poor metabolizer, intermediate metabolizer, or ultra-rapid metabolizer phenotypes were recommended different opioids to those with an extensive ('normal') metabolizer phenotype. Those in the control group did not receive CYP2D6-guided recommendations. Pain questionnaires were completed at baseline, 2, 4, 6, and 8 weeks. The trial is completed but results have not yet been published.

The authors cited evidence ranging from 1998 to 2017 (Figure 6). The oldest evidence was a 1998 RCT [133], cited alongside 5 other RCTs [134-138]. The newest evidence was 2017 guidelines on adult cancer pain from the National Comprehensive Cancer Network [139]. Interestingly, the trial cited three case studies; one in a patient with the poor metabolizer phenotype [140], and two with patients with the ultra-rapid metabolizer phenotype [141,142].

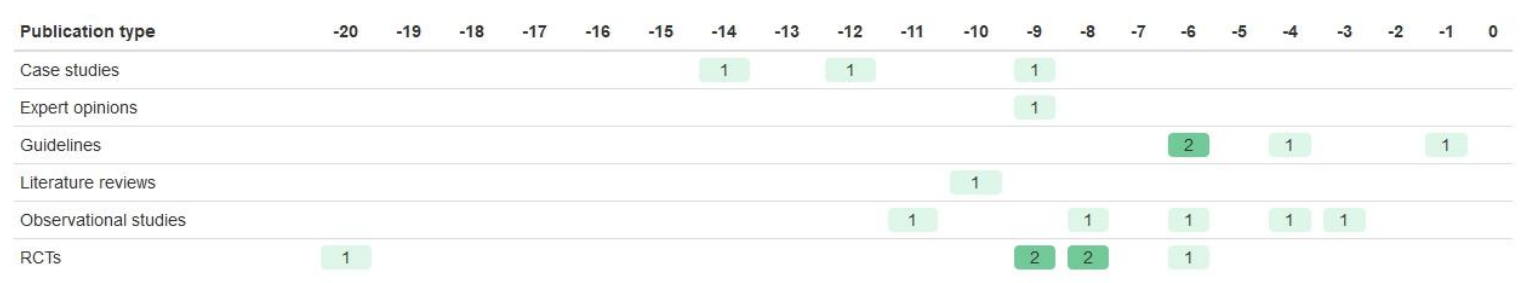

Figure 6. Evidence cited by the NCT02664350 trial to justify inclusion of the CYP2D6 biomarker, relative to the publication of the 2018 design and rationale paper [46].

\section{Discussion}

The trials in our review all used different approaches to gathering evidence for justifying biomarker inclusion, and there does not appear to be a standard approach to doing so. Of the trials examined, all cited evidence from within 3 years of their publication (Figure 1). The oldest evidence compared to trial start date was cited by the TARGET trial, which cited work from 25 years prior to its 2005 start date [54].

The evidence types used included systematic reviews/meta-analyses, RCTs, qualitative research, guidelines, recommendations, editorials, and case studies. The traditional 'evidence pyramid' is often used to rank evidence types, with meta-analyses and systematic reviews at the top, and case studies and in vitro evidence near the base [143]. However, this has seen some modification in recent years, notably the viewing of evidence through the 'lens' of systematic reviews and meta-analyses, ensuring that the quality of included studies is evaluated [144]. In this iteration, a meta-analysis based on weak evidence suffering from bias is not automatically seen as superior evidence to a well-conducted observational study.

To explore the type and extent of evidence compiled to justify including biomarkers in previous $\mathrm{BM}$ trials, we have referred to the references in the trial design paper or protocol. This represents 
a relatively straightforward method of assessing the evidence for a biomarker's inclusion in a trial, however has some inherent limitations. First, this method will not necessarily capture the entire evidence base upon which inclusion of the biomarker was justified, since the authors may not have provided a complete and accurate snapshot of the evidence they explored and used. Second, journal rules on the amount of references in a paper and word count restrictions could mean that the references included do not represent the totality of evidence used. Similar restrictions on references and word counts may limit the representation of the literature in protocols.

\section{Recommendations}

While the ideal level of evidence is a well-conducted meta-analysis/systematic review of good quality RCTs, including a rigorous assessment of their quality, this is not always available or feasible. In particular, where a biomarker is very new, there may be limited previous evidence to underpin its use. This evidence may take the form of case series or previous case studies. If this is the only evidence available, then this may be the 'best' evidence to justify including the biomarker in a trial. It would be important to consider, in such circumstances, whether the proposed RCT would be premature and that the science should first of all be allowed to mature.

It may be that different standards of evidence may be necessary for different biomarker types [25,145]. For example, evidence standards could be based on risk, with biomarkers for lower risk applications requiring less evidence and regulatory oversight than those for high risk applications [145]. Recommendations could also be based on the disease being treated, similar to how orphan drugs for rare diseases are given accelerated approvals $[146,147]$. Biomarkers used for more serious indications could be allowed to proceed to trial with less or lower quality evidence than biomarkers for less serious conditions. Novelty of the biomarker will also influence the extent of evidence available-for example a biomarker first utilised in 1980 is likely to have accumulated much more evidence than one first described in 2015.

Further, some conditions have existing diagnostic or treatment guidance algorithms that do not use biomarkers but have good clinical utility. In these scenarios, adding a biomarker to the algorithm might provide a low value of information compared to a biomarker used in a condition where a good clinical algorithm is not available. Therefore, authors might consider prioritizing the development of biomarkers for conditions that do not have sufficient clinical prediction methods for diagnosis or guiding treatment.

It is also important to ensure that genetic biomarkers are not subject to higher evidentiary requirements than other types of biomarkers. This 'genetic exceptionalism' and the higher burden of evidence for genetic tests has been shown to be a barrier to implementation $[4,25,30,148]$. Finally, biomarkers that are integral to a trial's conduct require more evidence than biomarkers used on an exploratory basis [41].

With these factors in mind, our recommendations for all biomarker-guided trials consist of two essentials (Figure 7).

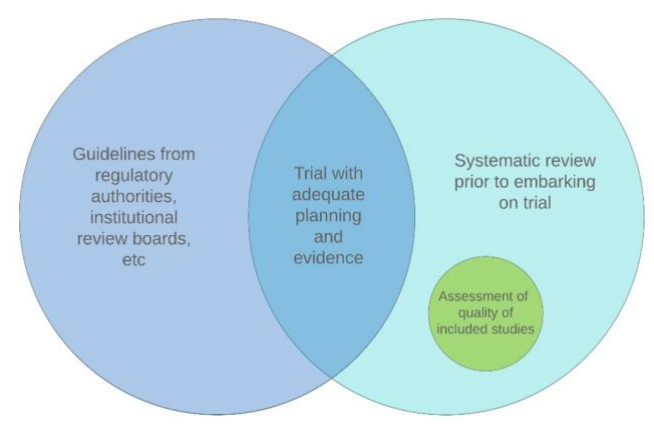

Figure 7. Our recommendations for evidence gathering prior to the start of a biomarker-guided trial, based on the findings of this review. 
- Systematic review before embarking on a trial

We would recommend an initial systematic review is undertaken prior to the start of any trial. The Lancet journal now requires all research papers to include a 'Research in Context' panel that shows the evidence available prior to the study, and how the authors searched for this information [149]. This is an important step that should be considered by all journals and particularly any source funding a clinical trial. The search should be supplemented with evidence from other sources such as clinical guidelines and pilot data.

Regardless of the type of evidence identified in the systematic review, we recommend that the quality of that evidence is assessed when justifying including the biomarker, and we suggest that design-specific tools are used for this purpose (e.g., the Cochrane Collaboration's Risk of Bias tool for RCTs) [150]. Several study type-specific methods for doing this are available [131,150-154] and have been reviewed by Zeng, et al. (2015) [155]. We additionally recommend the quality of pharmacogenetic studies is assessed using the guidelines proposed by Jorgensen and Williamson (2008) [156].

When synthesising evidence already existing from previous studies, it is also important to consider the age and ethnicities of the populations of the previous studies compared to the proposed trial's population to ensure that the evidence is relevant. Many studies ( $94 \%$ in one review [157]) imply generalisability of results without acknowledging the differential effects of race and ethnicity. Differences in cancer incidence, stage at discovery [158], and mortality [159] have been found to be functions of race or ethnicity and it is imperative that trialists consider the ethnicity of the proposed trial population and to keep this in mind when evaluating the evidence relating to biomarker validity. Notably, a 2016 review found that $81 \%$ of participants in genome-wide association studies were white [160], and several studies have shown that non-white people are less likely to be clinical trial participants $[157,161,162]$ and are less likely to access genetic testing services [163]. It is important, therefore, in a drive to reduce such inequalities, that the clinical utility of ethno-specific biomarkers are tested in trials recruiting participants from relevant ethnic backgrounds. Similar considerations should be given to other factors known to contribute to health inequalities, including age, gender, and socio-economic position. These factors are summarized by the PROGRESS-Plus acronym recommended by the Cochrane Public Health Group [164].

Further, if the systematic review reveals a sufficient number of previous RCTs or observational studies, authors should consider conducting a meta-analysis to assess the current evidence quantitatively. This would help ascertain whether there was sufficient uncertainty surrounding the current evidence to justify the planned RCT. An example of where this could have been implemented is in the fifth trial we examined [46]. Authors can also utilise funnel plots to examine any potential bias in the publication of included studies [165], and explore any heterogeneity between studies.

\section{- Guidelines are required}

Given the lack of standardisation across BM trials in terms of how inclusion of biomarkers are justified, we recommend that guidelines are developed to aid researchers in compiling and presenting evidence to justify their inclusions. This will not only ensure that sufficient evidence exists prior to embarking on a BM trial, thus avoiding waste of resources, but will also serve as a useful guide to those planning a BM trial and provide transparency in the trial report.

The Clinical Pharmacogenetics Implementation Consortium (CPIC) provides guidelines for the implementation of pharmacogenetics [166]. The guidelines provide a grading of the level of evidence given in support of the biomarker's implementation ('high', 'moderate' or 'weak') [167]. The CPIC levels are based on PharmGKB criteria (Figure 8), where the evidence for a gene-drug association is rated on a six-point scale between $1 \mathrm{~A}$ (guidelines endorsed by a medical society or major health system) to 4 (in vitro, case study, or nonsignificant study evidence) [29]. This scale is based on 'clinical annotations' obtained from PubMed, produced by combining and summarising associations from several publications. These clinical annotations are then given a 'level of evidence' score based 
on replication of the association, $p$-value, and odds ratio. The score is determined by PharmGKB curators [29].

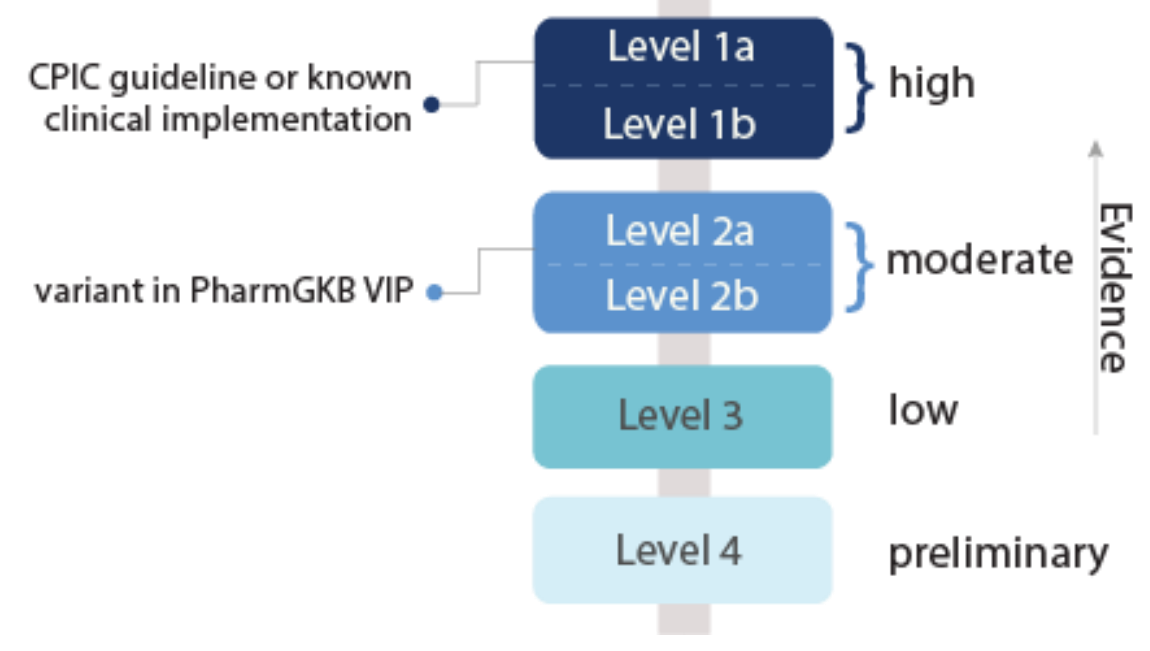

Figure 8. Guidelines of the Clinical Pharmacogenetics Implementation Consortium (CPIC) for the grading of biomarker evidence, based on the PharmGKB evidence criteria $[29,168]$.

Whilst these guidelines are for implementation of biomarkers into clinical practice in a patient who has a known genotype, a similar approach could be developed for justification of use in a RCT. We located one paper that discussed the incorporation of biomarkers into early phase clinical trials [41], but we recommend that this needs to contribute to the formation of formal guidelines for BM trials similar to CPIC guidelines for biomarker implementation.

Finally, the conclusions and recommendations above are based on the assumption that a BM trial is indeed required. It is possible that when compiling the evidence to justify inclusion of a biomarker in a trial that it is so overwhelmingly in favour of the biomarker's clinical utility that it may be unethical to restrict its use to a randomised trial. This loss of clinical equipoise is something important to consider and indeed clinical implementation may be recommended and accepted without the need for a BM trial in such cases.

Supplementary Materials: The following are available online at http://www.mdpi.com/2075-4426/9/3/42/s1.

Author Contributions: Conceptualization, D.J., A.J., D.H. and M.P.; Formal Analysis, D.J.; Investigation, D.J. and A.J.; Data Curation, D.J.; Writing-Original Draft Preparation, D.J. and A.J.; Writing-Review \& Editing, D.J., A.J., D.H. and M.P.; Visualization, D.J., A.J. and D.H.; Supervision, A.J., D.H., M.P.; Funding Acquisition, A.J., M.P.

Funding: This research/DJ is supported by a PhD studentship funded by the MRC Network of Hubs for Trials Methodology Research (MR/L004933/2-R19).

Conflicts of Interest: The authors declare no conflict of interest.

\section{References}

1. Teutsch, S.M.; Bradley, L.A.; Palomaki, G.E.; Haddow, J.E.; Piper, M.; Calonge, N.; Dotson, W.D.; Douglas, M.P.; Berg, A.O.; EGAPP Working Group. The Evaluation of Genomic Applications in Practice and Prevention (EGAPP) Initiative: Methods of the EGAPP Working Group. Genet. Med. 2009, 11,3-14. [CrossRef] [PubMed]

2. Williams-Jones, B.; Corrigan, O.P. Rhetoric and hype: where's thee thics in pharmacogenomics? Am. J. Pharm. 2003, 3, 375-383.

3. Buchanan, A.; Califano, A.; Kahn, J.; McPherson, E.; Robertson, J.; Brody, B. Pharmacogenetics: Ethical issues and policy options. Kennedy Inst. Ethics 2002, 12,1-15. [CrossRef] 
4. Pirmohamed, M. Acceptance of biomarker-based tests for application in clinical practice: Criteria and obstacles. Clin. Pharmacol. Ther. 2010, 88, 862-866. [CrossRef] [PubMed]

5. Pirmohamed, M.; Park, B.K. Genetic susceptibility to adverse drug reactions. Trends Pharm. Sci 2001, 22, 298-305. [CrossRef]

6. Biomarkers Definitions Working Group. Biomarkers and surrogate endpoints: Preferred definitions and conceptual framework. Clin. Pharmacol. Ther. 2001, 69, 89-95. [CrossRef] [PubMed]

7. Barker, A.D.; Sigman, C.C.; Kelloff, G.J.; Hylton, N.M.; Berry, D.A.; Esserman, L.J. I-SPY 2: An adaptive breast cancer trial design in the setting of neoadjuvant chemotherapy. Clin. Pharmacol. Ther. 2009, 86, 97-100. [CrossRef]

8. Weinberg, D.S.; Myers, R.E.; Keenan, E.; Ruth, K.; Sifri, R.; Ziring, B.; Ross, E.; Manne, S.L. Genetic and environmental risk assessment and colorectal cancer screening in an average-risk population: A randomized trial. Ann. Intern. Med. 2014, 161, 537-545. [CrossRef]

9. Pirmohamed, M.; Burnside, G.; Eriksson, N.; Jorgensen, A.L.; Toh, C.H.; Nicholson, T.; Kesteven, P.; Christersson, C.; Wahlstrom, B.; Stafberg, C.; et al. A randomized trial of genotype-guided dosing of warfarin. N. Engl. J. Med. 2013, 369, 2294-2303. [CrossRef]

10. Newman, W.G.; Payne, K.; Tricker, K.; Roberts, S.A.; Fargher, E.; Pushpakom, S.; Alder, J.E.; Sidgwick, G.P.; Payne, D.; Elliott, R.A.; et al. A pragmatic randomized controlled trial of thiopurine methyltransferase genotyping prior to azathioprine treatment: The TARGET study. Pharmacogenomics 2011, 12, 815-826. [CrossRef]

11. Siramshetty, V.B.; Nickel, J.; Omieczynski, C.; Gohlke, B.O.; Drwal, M.N.; Preissner, R. WITHDRAWNA resource for withdrawn and discontinued drugs. Nucleic Acids Res. 2015, 44, D1080-D1086. [CrossRef]

12. Onakpoya, I.J.; Heneghan, C.J.; Aronson, J.K. Worldwide withdrawal of medicinal products because of adverse drug reactions: A systematic review and analysis. Crit. Rev. Toxicol. 2016, 46, 477-489. [CrossRef] [PubMed]

13. Need, A.C.; Motulsky, A.G.; Goldstein, D.B. Priorities and standards in pharmacogenetic research. Nat. Genet. 2005, 37, 671-681. [CrossRef] [PubMed]

14. Pirmohamed, M.; James, S.; Meakin, S.; Green, C.; Scott, A.K.; Walley, T.J.; Farrar, K.; Park, B.K.; Breckenridge, A.M. Adverse drug reactions as cause of admission to hospital: Prospective analysis of 18820 patients. BMJ 2004, 329, 15-19. [CrossRef] [PubMed]

15. Laatikainen, O.; Miettunen, J.; Sneck, S.; Lehtiniemi, H.; Tenhunen, O.; Turpeinen, M. The prevalence of medication-related adverse events in inpatients-a systematic review and meta-analysis. Eur. J. Clin. Pharm. 2017, 73, 1539-1549. [CrossRef]

16. Verbelen, M.; Weale, M.E.; Lewis, C.M. Cost-effectiveness of pharmacogenetic-guided treatment: Are we there yet? Pharm. J. 2017, 17, 395-402. [CrossRef] [PubMed]

17. Plumpton, C.O.; Roberts, D.; Pirmohamed, M.; Hughes, D.A. A Systematic Review of Economic Evaluations of Pharmacogenetic Testing for Prevention of Adverse Drug Reactions. Pharmacoeconomics 2016, 34, 771-793. [CrossRef]

18. Mallal, S.; Phillips, E.; Carosi, G.; Molina, J.M.; Workman, C.; Tomazic, J.; Jagel-Guedes, E.; Rugina, S.; Kozyrev, O.; Cid, J.F.; et al. HLA-B*5701 screening for hypersensitivity to abacavir. N. Engl. J. Med. 2008, 358, 568-579. [CrossRef]

19. Hughes, D.A.; Vilar, F.J.; Ward, C.C.; Alfirevic, A.; Park, B.K.; Pirmohamed, M. Cost-effectiveness analysis of HLA B*5701 genotyping in preventing abacavir hypersensitivity. Pharmacogenetics 2004, 14, 335-342. [CrossRef]

20. Hughes, D.A. Economics of Pharmacogenetic-Guided Treatments: Underwhelming or Overstated? Clin. Pharmacol. Ther. 2018, 103, 749-751. [CrossRef]

21. Food and Drug Administration (US). Table of Pharmacogenomic Biomarkers in Drug Labeling. Available online: https://www.fda.gov/Drugs/ScienceResearch/ucm572698.htm (accessed on 25 July 2019).

22. Shuldiner, A.R.; Relling, M.V.; Peterson, J.F.; Hicks, J.K.; Freimuth, R.R.; Sadee, W.; Pereira, N.L.; Roden, D.M.; Johnson, J.A.; Klein, T.E.; et al. The Pharmacogenomics Research Network Translational Pharmacogenetics Program: Overcoming challenges of real-world implementation. Clin. Pharmacol. Ther. 2013, 94, 207-210. [CrossRef] [PubMed]

23. García-González, X.; Cabaleiro, T.; Herrero María, J.; McLeod, H.; López-Fernández Luis, A. Clinical implementation of pharmacogenetics. Drug Metab. Pers. Ther. 2016, 31, 9. [CrossRef] [PubMed] 
24. Slob, E.M.A.; Vijverberg, S.J.H.; Pijnenburg, M.W.; Koppelman, G.H.; Maitland-van der Zee, A.H. What do we need to transfer pharmacogenetics findings into the clinic? Pharmacogenomics 2018, 19, 589-592. [CrossRef] [PubMed]

25. Pirmohamed, M.; Hughes, D.A. Pharmacogenetic tests: The need for a level playing field. Nat. Rev. Drug Discov. 2013, 12, 3-4. [CrossRef] [PubMed]

26. Najafzadeh, M.; Davis, J.C.; Joshi, P.; Marra, C. Barriers for integrating personalized medicine into clinical practice: A qualitative analysis. Am. J. Med. Genet. Part A 2013, 16, 758-763. [CrossRef] [PubMed]

27. Chin, L.; Devine, B.; Baradaran, S.; Keyloun, K.; Canestaro, W.; Pham, J. Characterizing the Strength of Evidence in FDA Labels for Pharmacogenomic Biomarker-Guided Medication Use. Amia Summits Transl. Sci. Proc. 2017, 2017, 30-39. [PubMed]

28. Vivot, A.; Boutron, I.; Ravaud, P.; Porcher, R. Guidance for pharmacogenomic biomarker testing in labels of FDA-approved drugs. Genet. Med. 2015, 17, 733-738. [CrossRef] [PubMed]

29. Whirl-Carrillo, M.; McDonagh, E.M.; Hebert, J.M.; Gong, L.; Sangkuhl, K.; Thorn, C.F.; Altman, R.B.; Klein, T.E. Pharmacogenomics knowledge for personalized medicine. Clin. Pharmacol. Ther. 2012, 92, 414-417. [CrossRef] [PubMed]

30. van der Wouden, C.H.; Cambon-Thomsen, A.; Cecchin, E.; Cheung, K.C.; Davila-Fajardo, C.L.; Deneer, V.H.; Dolzan, V.; Ingelman-Sundberg, M.; Jonsson, S.; Karlsson, M.O.; et al. Implementing Pharmacogenomics in Europe: Design and Implementation Strategy of the Ubiquitous Pharmacogenomics Consortium. Clin. Pharmacol. Ther. 2017, 101, 341-358. [CrossRef]

31. Lesko, L.J.; Atkinson, A.J., Jr. Use of biomarkers and surrogate endpoints in drug development and regulatory decision making: Criteria, validation, strategies. Annu. Rev. Pharm. Toxicol. 2001, 41, 347-366. [CrossRef]

32. Rolan, P. The contribution of clinical pharmacology surrogates and models to drug development-A critical appraisal. Br. J. Clin. Pharmacol. 1997, 44, 219-225. [CrossRef] [PubMed]

33. Torgerson, D.; Torgerson, C. Designing Randomised Trials in Health, Education and the Social Sciences: An Introduction; Springer: Berlin/Heidelberg, Germany, 2008.

34. Barton, S. Which clinical studies provide the best evidence? The best RCT still trumps the best observational study. BMJ 2000, 321, 255-256. [CrossRef] [PubMed]

35. Hyde, P. Fool's Gold: Examining the Use of Gold Standards in the Production of Research Evidence. Br. J. Occup. Ther. 2016, 67, 89-94. [CrossRef]

36. Vivot, A.; Boutron, I.; Beraud-Chaulet, G.; Zeitoun, J.D.; Ravaud, P.; Porcher, R. Evidence for Treatment-by-Biomarker interaction for FDA-approved Oncology Drugs with Required Pharmacogenomic Biomarker Testing. Sci. Rep. 2017, 7, 6882. [CrossRef] [PubMed]

37. Poste, G. Bring on the biomarkers. Nature 2011, 469, 156-157. [CrossRef] [PubMed]

38. Antoniou, M.; Jorgensen, A.L.; Kolamunnage-Dona, R. Biomarker-Guided Adaptive Trial Designs in Phase II and Phase III: A Methodological Review. PLoS ONE 2016, 11, e0149803. [CrossRef] [PubMed]

39. Antoniou, M.; Jorgensen, A.L.; Kolamunnage-Dona, R. Biomarker-guided trial designs (BiGTeD): An online tool to help develop personalised medicine. Available online: http://www.bigted.org/ (accessed on 18 May 2018).

40. Antoniou, M.; Kolamunnage-Dona, R.; Jorgensen, A.L. Biomarker-Guided Non-Adaptive Trial Designs in Phase II and Phase III: A Methodological Review. J. Pers Med. 2017, 7, 1. [CrossRef]

41. Yee, L.M.; Lively, T.G.; McShane, L.M. Biomarkers in early-phase trials: Fundamental issues. Bioanalysis 2018, 10, 933-944. [CrossRef]

42. Hayes, D.F.; Allen, J.; Compton, C.; Gustavsen, G.; Leonard, D.G.; McCormack, R.; Newcomer, L.; Pothier, K.; Ransohoff, D.; Schilsky, R.L.; et al. Breaking a vicious cycle. Sci. Transl. Med. 2013, 5, 196cm6. [CrossRef]

43. Le Tourneau, C.; Delord, J.P.; Goncalves, A.; Gavoille, C.; Dubot, C.; Isambert, N.; Campone, M.; Tredan, O.; Massiani, M.A.; Mauborgne, C.; et al. Molecularly targeted therapy based on tumour molecular profiling versus conventional therapy for advanced cancer (SHIVA): A multicentre, open-label, proof-of-concept, randomised, controlled phase 2 trial. Lancet Oncol. 2015, 16, 1324-1334. [CrossRef]

44. Singh, K.; Peyser, B.; Trujillo, G.; Milazzo, N.; Savard, D.; Haga, S.B.; Musty, M.; Voora, D. Rationale and design of the SLCO1B1 genotype guided statin therapy trial. Pharmacogenomics 2016, 17, 1873-1880. [CrossRef] [PubMed]

45. Peyser, B.; Perry, E.P.; Singh, K.; Gill, R.D.; Mehan, M.R.; Haga, S.B.; Musty, M.D.; Milazzo, N.A.; Savard, D.; Li, Y.J.; et al. Effects of Delivering SLCO1B1 Pharmacogenetic Information in Randomized Trial and Observational Settings. Circ. Genom. Precis. Med. 2018, 11, e002228. [CrossRef] [PubMed] 
46. Mosley, S.A.; Hicks, J.K.; Portman, D.G.; Donovan, K.A.; Gopalan, P.; Schmit, J.; Starr, J.; Silver, N.; Gong, Y.; Langaee, T.; et al. Design and rational for the precision medicine guided treatment for cancer pain pragmatic clinical trial. Contemp. Clin. Trials 2018, 68, 7-13. [CrossRef] [PubMed]

47. Ollier, B.; Newman, B.; Payne, K.; Poulton, K.; Andrews, J.; Elliott, R.; Ray, D.; Elles, R.; Houston, B.; Bruce, I.; et al. University of Manchester, Manchester, UK. Personal communication, 2015.

48. Voora, D.; Singh, K.; Trujillo, G.; Milazzo, N.; Savard, D.; Haga, S.; Musty, M.D.; Li, Y.J.; Peyser, B. SLCO1B1 Genotype-Guided Statin Therapy Lowers LDL Cholesterol in Patients With Statin-Intolerance-A Randomized Controlled Trial. Circulation 2016, 134, A12183.

49. van Schie, R.M.; Wadelius, M.I.; Kamali, F.; Daly, A.K.; Manolopoulos, V.G.; de Boer, A.; Barallon, R.; Verhoef, T.I.; Kirchheiner, J.; Haschke-Becher, E.; et al. Genotype-guided dosing of coumarin derivatives: The European pharmacogenetics of anticoagulant therapy (EU-PACT) trial design. Pharmacogenomics 2009, 10, 1687-1695. [CrossRef]

50. R Studio Team. RStudio: Integrated Development for R; RStudio, Inc.: Boston, MA, USA, 2016.

51. Ren, K.; Russell, K. Package 'formattable'. Available online: https://cran.r-project.org/web/packages/ formattable/formattable.pdf (accessed on 25 July 2019).

52. Lucid Software Inc. Online Diagram Software: Lucidchart; Lucid Software Inc.: South Jordan, UT, USA, 2013.

53. Thompson, A.J.; Newman, W.G.; Elliott, R.A.; Roberts, S.A.; Tricker, K.; Payne, K. The cost-effectiveness of a pharmacogenetic test: A trial-based evaluation of TPMT genotyping for azathioprine. Value Health J. Int. Soc. Pharm. Outcomes Res. 2014, 17, 22-33. [CrossRef]

54. Weinshilboum, R.M.; Sladek, S.L. Mercaptopurine pharmacogenetics: Monogenic inheritance of erythrocyte thiopurine methyltransferase activity. Am. J. Hum. Genet. 1980, 32, 651-662.

55. Lennard, L.; Van Loon, J.A.; Weinshilboum, R.M. Pharmacogenetics of acute azathioprine toxicity: Relationship to thiopurine methyltransferase genetic polymorphism. Clin. Pharmacol. Ther. 1989, 46, 149-154. [CrossRef]

56. Dubinsky, M.C.; Lamothe, S.; Yang, H.Y.; Targan, S.R.; Sinnett, D.; Theoret, Y.; Seidman, E.G. Pharmacogenomics and metabolite measurement for 6-mercaptopurine therapy in inflammatory bowel disease. Gastroenterology 2000, 118, 705-713. [CrossRef]

57. McLeod, H.L.; Lin, J.S.; Scott, E.P.; Pui, C.H.; Evans, W.E. Thiopurine methyltransferase activity in American white subjects and black subjects. Clin. Pharmacol. Ther. 1994, 55, 15-20. [CrossRef]

58. Yates, C.R.; Krynetski, E.Y.; Loennechen, T.; Fessing, M.Y.; Tai, H.L.; Pui, C.H.; Relling, M.V.; Evans, W.E. Molecular diagnosis of thiopurine S-methyltransferase deficiency: Genetic basis for azathioprine and mercaptopurine intolerance. Ann. Intern. Med. 1997, 126, 608-614. [CrossRef] [PubMed]

59. Bloomfeld, R.S.; Onken, J.E. Mercaptopurine metabolite results in clinical gastroenterology practice. Aliment. Pharmacol. Ther. 2003, 17, 69-73. [CrossRef] [PubMed]

60. McLeod, H.L.; Coulthard, S.; Thomas, A.E.; Pritchard, S.C.; King, D.J.; Richards, S.M.; Eden, O.B.; Hall, A.G.; Gibson, B.E. Analysis of thiopurine methyltransferase variant alleles in childhood acute lymphoblastic leukaemia. Br. J. Haematol. 1999, 105, 696-700. [CrossRef] [PubMed]

61. Black, A.J.; McLeod, H.L.; Capell, H.A.; Powrie, R.H.; Matowe, L.K.; Pritchard, S.C.; Collie-Duguid, E.S.; Reid, D.M. Thiopurine methyltransferase genotype predicts therapy-limiting severe toxicity from azathioprine. Ann. Intern. Med. 1998, 129, 716-718. [CrossRef] [PubMed]

62. Pandya, B.; Thomson, W.; Poulton, K.; Bruce, I.; Payne, D.; Qasim, F. Azathioprine toxicity and thiopurine methyltransferase genotype in renal transplant patients. Transpl. Proc. 2002, 34, 1642-1645. [CrossRef]

63. Murphy, L.A.; Atherton, D. A retrospective evaluation of azathioprine in severe childhood atopic eczema, using thiopurine methyltransferase levels to exclude patients at high risk of myelosuppression. Br. J. Dermatol. 2002, 147, 308-315. [CrossRef] [PubMed]

64. Holme, S.A.; Duley, J.A.; Sanderson, J.; Routledge, P.A.; Anstey, A.V. Erythrocyte thiopurine methyl transferase assessment prior to azathioprine use in the UK. Qjm Mon. J. Assoc. Physicians 2002, 95, 439-444. [CrossRef]

65. Seidman, E.G. Clinical use and practical application of TPMT enzyme and 6-mercaptopurine metabolite monitoring in IBD. Rev. Gastroenterol. Disord. 2003, 3, S30-S38.

66. Marra, C.A.; Esdaile, J.M.; Anis, A.H. Practical pharmacogenetics: The cost effectiveness of screening for thiopurine s-methyltransferase polymorphisms in patients with rheumatological conditions treated with azathioprine. J. Rheumatol. 2002, 29, 2507-2512. 
67. Tavadia, S.M.; Mydlarski, P.R.; Reis, M.D.; Mittmann, N.; Pinkerton, P.H.; Shear, N.; Sauder, D.N. Screening for azathioprine toxicity: A pharmacoeconomic analysis based on a target case. J. Am. Acad. Dermatol. 2000, 42, 628-632. [CrossRef]

68. Tan, B.B.; Lear, J.T.; Gawkrodger, D.J.; English, J.S. Azathioprine in dermatology: A survey of current practice in the U.K. Br. J. Dermatol. 1997, 136, 351-355. [CrossRef] [PubMed]

69. Pirmohamed, M.; Stoddern, J.; Prince, C.; Toh, C.H.; Nicholson, T.; Kesteven, P.; Jorgensen, A.; Daly, A.; Maitland-van der Zee, A.H.; Williamson, P.; et al. A Randomized Trial Comparing Genotype-Guided Dosing of Warfarin to Standard Dosing: The EU Pharmacogenetics of Anticoagulant Therapy (EU-PACT) Warfarin Study. N. Engl. J. Med. 2013, 369, 2294-2303. [CrossRef] [PubMed]

70. Verhoef, T.I.; Ragia, G.; de Boer, A.; Barallon, R.; Kolovou, G.; Kolovou, V.; Konstantinides, S.; Le Cessie, S.; Maltezos, E.; van der Meer, F.J.; et al. A randomized trial of genotype-guided dosing of acenocoumarol and phenprocoumon. N. Engl. J. Med. 2013, 369, 2304-2312. [CrossRef] [PubMed]

71. Manolopoulos, V.G.; Ragia, G.; Tavridou, A.; Kolovou, V.; Kolovou, G.; Maltezos, E.; Tziakas, D.; Konstantinides, S. Effectiveness of Acenocoumarol Genetic and Clinical Dosing Algorithms in Predicting Stable Dose in the Greek Cohort of the Eu-Pact Trial. Clin. Ther. 2015, 37, E6. [CrossRef]

72. James, A.H.; Britt, R.P.; Raskino, C.L.; Thompson, S.G. Factors affecting the maintenance dose of warfarin. J. Clin. Pathol. 1992, 45, 704-706. [CrossRef] [PubMed]

73. Wadelius, M.; Chen, L.Y.; Lindh, J.D.; Eriksson, N.; Ghori, M.J.; Bumpstead, S.; Holm, L.; McGinnis, R.; Rane, A.; Deloukas, P. The largest prospective warfarin-treated cohort supports genetic forecasting. Blood 2009, 113, 784-792. [CrossRef]

74. Takeuchi, F.; McGinnis, R.; Bourgeois, S.; Barnes, C.; Eriksson, N.; Soranzo, N.; Whittaker, P.; Ranganath, V.; Kumanduri, V.; McLaren, W.; et al. A genome-wide association study confirms VKORC1, CYP2C9, and CYP4F2 as principal genetic determinants of warfarin dose. PLoS Genet. 2009, 5, e1000433. [CrossRef] [PubMed]

75. International Warfarin Pharmacogenetics Consortium; Klein, T.E.; Altman, R.B.; Eriksson, N.; Gage, B.F.; Kimmel, S.E.; Lee, M.T.; Limdi, N.A.; Page, D.; Roden, D.M.; et al. Estimation of the warfarin dose with clinical and pharmacogenetic data. N. Engl. J. Med. 2009, 360, 753-764.

76. Rosendaal, F.R. The Scylla and Charybdis of oral anticoagulant treatment. N. Engl. J. Med. 1996, 335, 587-589. [CrossRef]

77. Pirmohamed, M. Warfarin: Almost 60 years old and still causing problems. Br. J. Clin. Pharmacol. 2006, 62, 509-511. [CrossRef]

78. Eckman, M.H.; Rosand, J.; Greenberg, S.M.; Gage, B.F. Cost-effectiveness of using pharmacogenetic information in warfarin dosing for patients with nonvalvular atrial fibrillation. Ann. Intern. Med. 2009, 150, 73-83. [CrossRef] [PubMed]

79. Schalekamp, T.; Boink, G.J.; Visser, L.E.; Stricker, B.H.; de Boer, A.; Klungel, O.H. CYP2C9 genotyping in acenocoumarol treatment: Is it a cost-effective addition to international normalized ratio monitoring? Clin. Pharmacol. Ther. 2006, 79, 511-520. [CrossRef] [PubMed]

80. Hughes, D.A.; Pirmohamed, M. Warfarin pharmacogenetics: Economic considerations. Pharmacoeconomics 2007, 25, 899-902. [CrossRef] [PubMed]

81. Tarcic, G.; Kamal, M.; Edelheit, O.; Barbash, Z.; Vidne, M.; Miron, B.; Callens, C.; Servant, N.; Bieche, I.; Le Tourneau, C. Functional mutational analysis to assess the oncogenic activity of variant of uncertain significance (VUS) detected in patients included in the SHIVA trial. Eur. J. Cancer 2016, 69, S6-S7. [CrossRef]

82. Kamal, M.; Servant, N.; Pierron, G.; Callens, C.; Gentien, D.; Lermine, A.; Lucotte, G.; Bernard, V.; Vincent-Salomon, A.; Bièche, I.; et al. Abstract 1524: Mutations and gene copy number variations landscape of metastases of various cancer types from patients enrolled in the SHIVA trial. Cancer Res. 2016, 76, 1524.

83. Thatcher, N.; Chang, A.; Parikh, P.; Rodrigues Pereira, J.; Ciuleanu, T.; von Pawel, J.; Thongprasert, S.; Tan, E.H.; Pemberton, K.; Archer, V.; et al. Gefitinib plus best supportive care in previously treated patients with refractory advanced non-small-cell lung cancer: Results from a randomised, placebo-controlled, multicentre study (Iressa Survival Evaluation in Lung Cancer). Lancet 2005, 366, 1527-1537. [CrossRef]

84. Mok, T.S.; Wu, Y.L.; Thongprasert, S.; Yang, C.H.; Chu, D.T.; Saijo, N.; Sunpaweravong, P.; Han, B.; Margono, B.; Ichinose, Y.; et al. Gefitinib or carboplatin-paclitaxel in pulmonary adenocarcinoma. N. Engl. J. Med. 2009, 361, 947-957. [CrossRef] 
85. Slamon, D.J.; Leyland-Jones, B.; Shak, S.; Fuchs, H.; Paton, V.; Bajamonde, A.; Fleming, T.; Eiermann, W.; Wolter, J.; Pegram, M.; et al. Use of chemotherapy plus a monoclonal antibody against HER2 for metastatic breast cancer that overexpresses HER2. N. Engl. J. Med. 2001, 344, 783-792. [CrossRef]

86. Lievre, A.; Bachet, J.B.; Boige, V.; Cayre, A.; Le Corre, D.; Buc, E.; Ychou, M.; Bouche, O.; Landi, B.; Louvet, C.; et al. KRAS mutations as an independent prognostic factor in patients with advanced colorectal cancer treated with cetuximab. J. Clin. Oncol. Off. J. Am. Soc. Clin. Oncol. 2008, 26, 374-379. [CrossRef]

87. Von Hoff, D.D.; Stephenson, J.J., Jr.; Rosen, P.; Loesch, D.M.; Borad, M.J.; Anthony, S.; Jameson, G.; Brown, S.; Cantafio, N.; Richards, D.A.; et al. Pilot study using molecular profiling of patients' tumors to find potential targets and select treatments for their refractory cancers. J. Clin. Oncol. Off. J. Am. Soc. Clin. Oncol. 2010, 28, 4877-4883. [CrossRef]

88. Doroshow, J.H. Selecting systemic cancer therapy one patient at a time: Is there a role for molecular profiling of individual patients with advanced solid tumors? J. Clin. Oncol. Off. J. Am. Soc. Clin. Oncol. 2010, 28, 4869-4871. [CrossRef] [PubMed]

89. Sosman, J.A.; Kim, K.B.; Schuchter, L.; Gonzalez, R.; Pavlick, A.C.; Weber, J.S.; McArthur, G.A.; Hutson, T.E.; Moschos, S.J.; Flaherty, K.T.; et al. Survival in BRAF V600-mutant advanced melanoma treated with vemurafenib. N. Engl. J. Med. 2012, 366, 707-714. [CrossRef] [PubMed]

90. Druker, B.J.; Talpaz, M.; Resta, D.J.; Peng, B.; Buchdunger, E.; Ford, J.M.; Lydon, N.B.; Kantarjian, H.; Capdeville, R.; Ohno-Jones, S.; et al. Efficacy and safety of a specific inhibitor of the BCR-ABL tyrosine kinase in chronic myeloid leukemia. N. Engl. J. Med. 2001, 344, 1031-1037. [CrossRef] [PubMed]

91. Sekulic, A.; Migden, M.R.; Oro, A.E.; Dirix, L.; Lewis, K.D.; Hainsworth, J.D.; Solomon, J.A.; Yoo, S.; Arron, S.T.; Friedlander, P.A.; et al. Efficacy and safety of vismodegib in advanced basal-cell carcinoma. N. Engl. J. Med. 2012, 366, 2171-2179. [CrossRef] [PubMed]

92. Tsimberidou, A.M.; Iskander, N.G.; Hong, D.S.; Wheler, J.J.; Falchook, G.S.; Fu, S.; Piha-Paul, S.; Naing, A.; Janku, F.; Luthra, R.; et al. Personalized medicine in a phase I clinical trials program: The MD Anderson Cancer Center initiative. Clin. Cancer Res. Off. J. Am. Assoc. Cancer Res. 2012, 18, 6373-6383. [CrossRef] [PubMed]

93. Shaw, A.T.; Kim, D.W.; Nakagawa, K.; Seto, T.; Crino, L.; Ahn, M.J.; De Pas, T.; Besse, B.; Solomon, B.J.; Blackhall, F.; et al. Crizotinib versus chemotherapy in advanced ALK-positive lung cancer. N. Engl. J. Med. 2013, 368, 2385-2394. [CrossRef]

94. Slamon, D.; Eiermann, W.; Robert, N.; Pienkowski, T.; Martin, M.; Press, M.; Mackey, J.; Glaspy, J.; Chan, A.; Pawlicki, M.; et al. Adjuvant trastuzumab in HER2-positive breast cancer. N. Engl. J. Med. 2011, 365, 1273-1283. [CrossRef]

95. Maemondo, M.; Inoue, A.; Kobayashi, K.; Sugawara, S.; Oizumi, S.; Isobe, H.; Gemma, A.; Harada, M.; Yoshizawa, H.; Kinoshita, I.; et al. Gefitinib or chemotherapy for non-small-cell lung cancer with mutated EGFR. N. Engl. J. Med. 2010, 362, 2380-2388. [CrossRef]

96. Ramsey, L.B.; Johnson, S.G.; Caudle, K.E.; Haidar, C.E.; Voora, D.; Wilke, R.A.; Maxwell, W.D.; McLeod, H.L.; Krauss, R.M.; Roden, D.M.; et al. The clinical pharmacogenetics implementation consortium guideline for SLCO1B1 and simvastatin-induced myopathy: 2014 update. Clin. Pharmacol. Ther. 2014, 96, 423-428. [CrossRef]

97. Wilke, R.A.; Ramsey, L.B.; Johnson, S.G.; Maxwell, W.D.; McLeod, H.L.; Voora, D.; Krauss, R.M.; Roden, D.M.; Feng, Q.; Cooper-Dehoff, R.M.; et al. The clinical pharmacogenomics implementation consortium: CPIC guideline for SLCO1B1 and simvastatin-induced myopathy. Clin. Pharmacol. Ther. 2012, 92, 112-117. [CrossRef]

98. Stone, N.J.; Robinson, J.G.; Lichtenstein, A.H.; Bairey Merz, C.N.; Blum, C.B.; Eckel, R.H.; Goldberg, A.C.; Gordon, D.; Levy, D.; Lloyd-Jones, D.M.; et al. 2013 ACC/AHA Guideline on the Treatment of Blood Cholesterol to Reduce Atherosclerotic Cardiovascular Risk in Adults. J. Am. Coll. Cardiol. 2014, 63, 2889-2934. [CrossRef] [PubMed]

99. Pasternak, R.C.; Smith, S.C.; Bairey-Merz, C.N.; Grundy, S.M.; Cleeman, J.I.; Lenfant, C. ACC/AHA/NHLBI clinical advisory on the use and safety of statins. J. Am. Coll. Cardiol. 2002, 40,567-572. [CrossRef]

100. Stroes, E.S.; Thompson, P.D.; Corsini, A.; Vladutiu, G.D.; Raal, F.J.; Ray, K.K.; Roden, M.; Stein, E.; Tokgozoglu, L.; Nordestgaard, B.G.; et al. Statin-associated muscle symptoms: Impact on statin therapy-European Atherosclerosis Society Consensus Panel Statement on Assessment, Aetiology and Management. Eur. Heart J. 2015, 36, 1012-1022. [CrossRef] [PubMed] 
101. Mozaffarian, D.; Benjamin, E.J.; Go, A.S.; Arnett, D.K.; Blaha, M.J.; Cushman, M.; de Ferranti, S.; Després, J.-P.; Fullerton, H.J.; Howard, V.J.; et al. Executive Summary: Heart Disease and Stroke Statistics—2015 Update. Circulation 2015, 131, 434-441. [CrossRef]

102. Alfirevic, A.; Neely, D.; Armitage, J.; Chinoy, H.; Cooper, R.G.; Laaksonen, R.; Carr, D.F.; Bloch, K.M.; Fahy, J.; Hanson, A.; et al. Phenotype standardization for statin-induced myotoxicity. Clin. Pharmacol. Ther. 2014, 96, 470-476. [CrossRef] [PubMed]

103. Ong, F.S.; Deignan, J.L.; Kuo, J.Z.; Bernstein, K.E.; Rotter, J.I.; Grody, W.W.; Das, K. Clinical utility of pharmacogenetic biomarkers in cardiovascular therapeutics: A challenge for clinical implementation. Pharmacogenomics 2012, 13, 465-475. [CrossRef] [PubMed]

104. Voora, D.; Ginsburg, G.S. Clinical application of cardiovascular pharmacogenetics. J. Am. Coll. Cardiol. 2012, 60, 9-20. [CrossRef]

105. Patel, J.; Superko, H.R.; Martin, S.S.; Blumenthal, R.S.; Christopher-Stine, L. Genetic and immunologic susceptibility to statin-related myopathy. Atherosclerosis 2015, 240, 260-271. [CrossRef]

106. Hirsh, B.J.; Smilowitz, N.R.; Rosenson, R.S.; Fuster, V.; Sperling, L.S. Utilization of and Adherence to Guideline-Recommended Lipid-Lowering Therapy After Acute Coronary Syndrome: Opportunities for Improvement. J. Am. Coll. Cardiol. 2015, 66, 184-192. [CrossRef]

107. Osterberg, L.; Blaschke, T. Adherence to medication. N. Engl. J. Med. 2005, 353, 487-497. [CrossRef]

108. Niemi, M.; Pasanen, M.K.; Neuvonen, P.J. Organic anion transporting polypeptide 1B1: A genetically polymorphic transporter of major importance for hepatic drug uptake. Pharm. Rev. 2011, 63, 157-181. [CrossRef] [PubMed]

109. Greenland, P.; Lauer, M.S. Cholesterol Lowering in 2015: Still Answering Questions About How and in Whom. JAMA 2015, 314, 127-128. [CrossRef]

110. Thompson, P.D.; Clarkson, P.M.; Rosenson, R.S. National Lipid Association Statin Safety Task Force Muscle Safety Expert, P. An assessment of statin safety by muscle experts. Am. J. Cardiol. 2006, 97, 69C-76C. [CrossRef] [PubMed]

111. Search Collaborative Group; Link, E.; Parish, S.; Armitage, J.; Bowman, L.; Heath, S.; Matsuda, F.; Gut, I.; Lathrop, M.; Collins, R. SLCO1B1 variants and statin-induced myopathy-a genomewide study. N. Engl. J. Med. 2008, 359, 789-799. [PubMed]

112. Pencina, M.J.; Navar-Boggan, A.M.; D'Agostino, R.B., Sr.; Williams, K.; Neely, B.; Sniderman, A.D.; Peterson, E.D. Application of new cholesterol guidelines to a population-based sample. N. Engl. J. Med. 2014, 370, 1422-1431. [CrossRef] [PubMed]

113. Bermingham, M.; Hayden, J.; Dawkins, I.; Miwa, S.; Gibson, D.; McDonald, K.; Ledwidge, M. Prospective analysis of LDL-C goal achievement and self-reported medication adherence among statin users in primary care. Clin. Ther. 2011, 33, 1180-1189. [CrossRef]

114. Ho, P.M.; Magid, D.J.; Shetterly, S.M.; Olson, K.L.; Maddox, T.M.; Peterson, P.N.; Masoudi, F.A.; Rumsfeld, J.S. Medication nonadherence is associated with a broad range of adverse outcomes in patients with coronary artery disease. Am. Heart J. 2008, 155, 772-779. [CrossRef]

115. Vodonos, A.; Ostapenko, I.; Toledano, R.; Henkin, Y.; Zahger, D.; Wolak, T.; Sherf, M.; Novack, V. Statin adherence and LDL cholesterol levels. Should we assess adherence prior to statin upgrade? Eur. J. Intern. Med. 2015, 26, 268-272. [CrossRef]

116. Franklin, J.M.; Krumme, A.A.; Tong, A.Y.; Shrank, W.H.; Matlin, O.S.; Brennan, T.A.; Choudhry, N.K. Association between trajectories of statin adherence and subsequent cardiovascular events. Pharm. Drug Saf. 2015, 24, 1105-1113. [CrossRef]

117. Pasanen, M.K.; Backman, J.T.; Neuvonen, P.J.; Niemi, M. Frequencies of single nucleotide polymorphisms and haplotypes of organic anion transporting polypeptide 1B1 SLCO1B1 gene in a Finnish population. Eur. J. Clin. Pharm. 2006, 62, 409-415. [CrossRef]

118. Li, J.H.; Joy, S.V.; Haga, S.B.; Orlando, L.A.; Kraus, W.E.; Ginsburg, G.S.; Voora, D. Genetically guided statin therapy on statin perceptions, adherence, and cholesterol lowering: A pilot implementation study in primary care patients. J. Pers. Med. 2014, 4, 147-162. [CrossRef] [PubMed]

119. Donnelly, L.A.; Doney, A.S.; Tavendale, R.; Lang, C.C.; Pearson, E.R.; Colhoun, H.M.; McCarthy, M.I.; Hattersley, A.T.; Morris, A.D.; Palmer, C.N. Common nonsynonymous substitutions in SLCO1B1 predispose to statin intolerance in routinely treated individuals with type 2 diabetes: A go-DARTS study. Clin. Pharmacol. Ther. 2011, 89, 210-216. [CrossRef] [PubMed] 
120. Birmingham, B.K.; Bujac, S.R.; Elsby, R.; Azumaya, C.T.; Wei, C.; Chen, Y.; Mosqueda-Garcia, R.; Ambrose, H.J. Impact of ABCG2 and SLCO1B1 polymorphisms on pharmacokinetics of rosuvastatin, atorvastatin and simvastatin acid in Caucasian and Asian subjects: A class effect? Eur. J. Clin. Pharm. 2015, 71, 341-355. [CrossRef] [PubMed]

121. de Keyser, C.E.; Peters, B.J.; Becker, M.L.; Visser, L.E.; Uitterlinden, A.G.; Klungel, O.H.; Verstuyft, C.; Hofman, A.; Maitland-van der Zee, A.H.; Stricker, B.H. The SLCO1B1 c. 521T> C polymorphism is associated with dose decrease or switching during statin therapy in the Rotterdam Study. Pharm. Genom. 2014, 24, 43-51. [CrossRef] [PubMed]

122. Voora, D.; Shah, S.H.; Spasojevic, I.; Ali, S.; Reed, C.R.; Salisbury, B.A.; Ginsburg, G.S. The SLCO1B1*5 genetic variant is associated with statin-induced side effects. J. Am. Coll. Cardiol. 2009, 54, 1609-1616. [CrossRef] [PubMed]

123. Danik, J.S.; Chasman, D.I.; MacFadyen, J.G.; Nyberg, F.; Barratt, B.J.; Ridker, P.M. Lack of association between SLCO1B1 polymorphisms and clinical myalgia following rosuvastatin therapy. Am. Heart J. 2013, 165, 1008-1014. [CrossRef] [PubMed]

124. Martin, N.G.; Li, K.W.; Murray, H.; Putt, W.; Packard, C.J.; Humphries, S.E. The effects of a single nucleotide polymorphism in SLCO1B1 on the pharmacodynamics of pravastatin. Br. J. Clin. Pharmacol. 2012, 73, 303-306. [CrossRef]

125. Taylor, F.; Huffman, M.D.; Macedo, A.F.; Moore, T.H.; Burke, M.; Davey Smith, G.; Ward, K.; Ebrahim, S. Statins for the primary prevention of cardiovascular disease. Cochrane Database Syst. Rev. 2013, 31, CD004816. [CrossRef]

126. De Vera, M.A.; Bhole, V.; Burns, L.C.; Lacaille, D. Impact of statin adherence on cardiovascular disease and mortality outcomes: A systematic review. Br. J. Clin. Pharmacol. 2014, 78, 684-698. [CrossRef]

127. Cholesterol Treatment Trialists Collaborators. The effects of lowering LDL cholesterol with statin therapy in people at low risk of vascular disease: Meta-analysis of individual data from 27 randomised trials. Lancet 2012, 380, 581-590. [CrossRef]

128. Cholesterol Treatment Trialists Collaborators. Efficacy and safety of LDL-lowering therapy among men and women: Meta-analysis of individual data from 174,000 participants in 27 randomised trials. Lancet 2015, 385, 1397-1405. [CrossRef]

129. Hou, Q.; Li, S.; Li, L.; Li, Y.; Sun, X.; Tian, H. Association Between SLCO1B1 Gene T521C Polymorphism and Statin-Related Myopathy Risk: A Meta-Analysis of Case-Control Studies. Medicine 2015, 94, e1268. [CrossRef] [PubMed]

130. Peterson, A.M.; Nau, D.P.; Cramer, J.A.; Benner, J.; Gwadry-Sridhar, F.; Nichol, M. A checklist for medication compliance and persistence studies using retrospective databases. Value Health J. Int. Soc. Pharm. Outcomes Res. 2007, 10, 3-12. [CrossRef] [PubMed]

131. Stang, A. Critical evaluation of the Newcastle-Ottawa scale for the assessment of the quality of nonrandomized studies in meta-analyses. Eur. J. Epidemiol. 2010, 25, 603-605. [CrossRef] [PubMed]

132. Cholesterol Treatment Trialists Collaborators. CTT Collaboration. Available online: https://www. cttcollaboration.org/ (accessed on 26 February 2019).

133. Eckhardt, K.; Li, S.; Ammon, S.; Schanzle, G.; Mikus, G.; Eichelbaum, M. Same incidence of adverse drug events after codeine administration irrespective of the genetically determined differences in morphine formation. Pain 1998, 76, 27-33. [CrossRef]

134. Temel, J.S.; Greer, J.A.; Muzikansky, A.; Gallagher, E.R.; Admane, S.; Jackson, V.A.; Dahlin, C.M.; Blinderman, C.D.; Jacobsen, J.; Pirl, W.F.; et al. Early palliative care for patients with metastatic non-small-cell lung cancer. N. Engl. J. Med. 2010, 363, 733-742. [CrossRef]

135. Angst, M.S.; Phillips, N.G.; Drover, D.R.; Tingle, M.; Ray, A.; Swan, G.E.; Lazzeroni, L.C.; Clark, J.D. Pain sensitivity and opioid analgesia: A pharmacogenomic twin study. Pain 2012, 153, 1397-1409. [CrossRef]

136. Lotsch, J.; Rohrbacher, M.; Schmidt, H.; Doehring, A.; Brockmoller, J.; Geisslinger, G. Can extremely low or high morphine formation from codeine be predicted prior to therapy initiation? Pain 2009, 144, 119-124. [CrossRef]

137. Samer, C.F.; Daali, Y.; Wagner, M.; Hopfgartner, G.; Eap, C.B.; Rebsamen, M.C.; Rossier, M.F.; Hochstrasser, D.; Dayer, P.; Desmeules, J.A. The effects of CYP2D6 and CYP3A activities on the pharmacokinetics of immediate release oxycodone. Br. J. Pharm. 2010, 160, 907-918. [CrossRef] 
138. Zwisler, S.T.; Enggaard, T.P.; Noehr-Jensen, L.; Pedersen, R.S.; Mikkelsen, S.; Nielsen, F.; Brosen, K.; Sindrup, S.H. The hypoalgesic effect of oxycodone in human experimental pain models in relation to the CYP2D6 oxidation polymorphism. Basic Clin. Pharm. Toxicol. 2009, 104, 335-344. [CrossRef]

139. National Comprehensive Cancer Network. NCCN Clinical Practice Guidelines in Oncology: Adult Cancer Pain. Version 2. 2016. Available online: https://www.nccn.org/professionals/physician_gls/default.aspx (accessed on 21 August 2019).

140. Susce, M.T.; Murray-Carmichael, E.; de Leon, J. Response to hydrocodone, codeine and oxycodone in a CYP2D6 poor metabolizer. Prog. Neuropsychopharmacol. Biol. Psychiatry 2006, 30, 1356-1358. [CrossRef] [PubMed]

141. Ciszkowski, C.; Madadi, P.; Phillips, M.S.; Lauwers, A.E.; Koren, G. Codeine, ultrarapid-metabolism genotype, and postoperative death. N. Engl. J. Med. 2009, 361, 827-828. [CrossRef] [PubMed]

142. Gasche, Y.; Daali, Y.; Fathi, M.; Chiappe, A.; Cottini, S.; Dayer, P.; Desmeules, J. Codeine intoxication associated with ultrarapid CYP2D6 metabolism. N. Engl. J. Med. 2004, 351, 2827-2831. [CrossRef] [PubMed]

143. Rawlins, M. De Testimonio: On the evidence for decisions about the use of therapeutic interventions. Clin. Med. (Lond. Engl.) 2008, 8, 579-588. [CrossRef] [PubMed]

144. Murad, M.H.; Asi, N.; Alsawas, M.; Alahdab, F. New evidence pyramid. Evid. Based Med. 2016, $21,125-127$. [CrossRef] [PubMed]

145. Amur, S.; LaVange, L.; Zineh, I.; Buckman-Garner, S.; Woodcock, J. Biomarker Qualification: Toward a Multiple Stakeholder Framework for Biomarker Development, Regulatory Acceptance, and Utilization. Clin. Pharmacol. Ther. 2015, 98, 34-46. [CrossRef]

146. Gammie, T.; Lu, C.Y.; Babar, Z.U. Access to Orphan Drugs: A Comprehensive Review of Legislations, Regulations and Policies in 35 Countries. PLoS ONE 2015, 10, e0140002. [CrossRef]

147. Hughes, D.A.; Plumpton, C.O. Rare disease prevention and treatment: The need for a level playing field. Pharmacogenomics 2018, 19, 243-247. [CrossRef]

148. Green, M.J.; Botkin, J.R. "Genetic exceptionalism” in medicine: Clarifying the differences between genetic and nongenetic tests. Ann. Intern. Med. 2003, 138, 571-575. [CrossRef]

149. The Lancet. Information for Authors. Available online: https:/els-jbs-prod-cdn.literatumonline.com/pb/ assets/raw/Lancet/authors/tl-info-for-authors-1530878364923.pdf (accessed on 18 October 2018).

150. Higgins, J.P.; Altman, D.G.; Gotzsche, P.C.; Juni, P.; Moher, D.; Oxman, A.D.; Savovic, J.; Schulz, K.F.; Weeks, L.; Sterne, J.A.; et al. The Cochrane Collaboration's tool for assessing risk of bias in randomised trials. BMJ 2011, 343, d5928. [CrossRef]

151. Guyatt, G.H.; Oxman, A.D.; Vist, G.E.; Kunz, R.; Falck-Ytter, Y.; Alonso-Coello, P.; Schunemann, H.J.; Group, G.W. GRADE: An emerging consensus on rating quality of evidence and strength of recommendations. BMJ 2008, 336, 924-926. [CrossRef] [PubMed]

152. Von Elm, E.; Altman, D.G.; Egger, M.; Pocock, S.J.; Gøtzsche, P.C.; Vandenbroucke, J.P. The Strengthening the Reporting of Observational Studies in Epidemiology (STROBE) statement: Guidelines for reporting observational studies. Ann. Intern. Med. 2007, 147, 573-577. [CrossRef] [PubMed]

153. Altar, C.A.; Amakye, D.; Bounos, D.; Bloom, J.; Clack, G.; Dean, R.; Devanarayan, V.; Fu, D.; Furlong, S.; Hinman, L.; et al. A prototypical process for creating evidentiary standards for biomarkers and diagnostics. Clin. Pharmacol. Ther. 2008, 83, 368-371. [CrossRef] [PubMed]

154. Sterne, J.A.; Hernan, M.A.; Reeves, B.C.; Savovic, J.; Berkman, N.D.; Viswanathan, M.; Henry, D.; Altman, D.G.; Ansari, M.T.; Boutron, I.; et al. ROBINS-I: A tool for assessing risk of bias in non-randomised studies of interventions. BMJ 2016, 355, i4919. [CrossRef] [PubMed]

155. Zeng, X.; Zhang, Y.; Kwong, J.S.; Zhang, C.; Li, S.; Sun, F.; Niu, Y.; Du, L. The methodological quality assessment tools for preclinical and clinical studies, systematic review and meta-analysis, and clinical practice guideline: A systematic review. J. Evid. Based Med. 2015, 8, 2-10. [CrossRef] [PubMed]

156. Jorgensen, A.L.; Williamson, P.R. Methodological quality of pharmacogenetic studies: Issues of concern. Stat. Med. 2008, 27, 6547-6569. [CrossRef] [PubMed]

157. Geller, S.E.; Koch, A.; Pellettieri, B.; Carnes, M. Inclusion, analysis, and reporting of sex and race/ethnicity in clinical trials: Have we made progress? J. Womens Health 2011, 20, 315-320. [CrossRef]

158. Ghafoor, A.; Jemal, A.; Ward, E.; Cokkinides, V.; Smith, R.; Thun, M. Trends in breast cancer by race and ethnicity. CA Cancer J. Clin. 2003, 53, 342-355. [CrossRef] 
159. Ward, E.; Jemal, A.; Cokkinides, V.; Singh, G.K.; Cardinez, C.; Ghafoor, A.; Thun, M. Cancer disparities by race/ethnicity and socioeconomic status. CA Cancer J. Clin. 2004, 54, 78-93. [CrossRef]

160. Popejoy, A.B.; Fullerton, S.M. Genomics is failing on diversity. Nature 2016, 538, 161-164. [CrossRef]

161. Murthy, V.H.; Krumholz, H.M.; Gross, C.P. Participation in cancer clinical trials: Race-, sex-, and age-based disparities. JAMA 2004, 291, 2720-2726. [CrossRef] [PubMed]

162. Suther, S.; Kiros, G.E. Barriers to the use of genetic testing: A study of racial and ethnic disparities. Genet. Med. 2009, 11, 655-662. [CrossRef] [PubMed]

163. Forman, A.D.; Hall, M.J. Influence of race/ethnicity on genetic counseling and testing for hereditary breast and ovarian cancer. Breast J. 2009, 15, S56-S62. [CrossRef] [PubMed]

164. Kavanagh, J.; Oliver, S.; Lorenc, T. Reflections on developing and using PROGRESS-Plus. Equity Update 2008, 2, 1-3.

165. Sterne, J.A.; Sutton, A.J.; Ioannidis, J.P.; Terrin, N.; Jones, D.R.; Lau, J.; Carpenter, J.; Rucker, G.; Harbord, R.M.; Schmid, C.H.; et al. Recommendations for examining and interpreting funnel plot asymmetry in meta-analyses of randomised controlled trials. BMJ 2011, 343, d4002. [CrossRef] [PubMed]

166. Relling, M.V.; Klein, T.E. CPIC: Clinical Pharmacogenetics Implementation Consortium of the Pharmacogenomics Research Network. Clin. Pharmacol. Ther. 2011, 89, 464-467. [CrossRef] [PubMed]

167. Clinical Pharmacogenetics Implementation Consortium. Levels of Evidence. Available online: https://cpicpgx. org/levels-of-evidence/ (accessed on 25 March 2019).

168. PharmGKB. Clinical Annotation Levels of Evidence. Available online: https://www.pharmgkb.org/page/ clinAnnLevels (accessed on 25 March 2018).

(C) 2019 by the authors. Licensee MDPI, Basel, Switzerland. This article is an open access article distributed under the terms and conditions of the Creative Commons Attribution (CC BY) license (http://creativecommons.org/licenses/by/4.0/). 